\title{
Effects of Mn partitioning on nanoscale precipitation and mechanical properties of ferritic steels strengthened by NiAl nanoparticles
}

\author{
Z.B. Jiao, ${ }^{\mathrm{a}}$ J.H. Luan, ${ }^{\mathrm{a}}$ M.K. Miller, ${ }^{\mathrm{b}}$ C.Y. Yu ${ }^{\mathrm{a}}$ and C.T. Liu ${ }^{\mathrm{a}, *}$

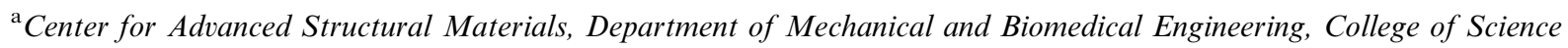 \\ and Engineering, City University of Hong Kong, Hong Kong, China \\ ${ }^{\mathrm{b}}$ Center for Nanophase Materials Sciences, Oak Ridge National Laboratory, Oak Ridge, TN 37831, USA
}

Received 27 September 2014; revised 31 October 2014; accepted 31 October 2014

\begin{abstract}
The critical role of Mn partitioning in the formation of ordered NiAl nanoparticles in ferritic steels has been examined through a combination of atom probe tomography (APT) and thermodynamic and first-principles calculations. Our APT study reveals that Mn partitions to the $\mathrm{NiAl}$ nanoparticles, and dramatically increases the particle number density by more than an order of magnitude, leading to a threefold enhancement in strengthening. Atomistic structural analyses reveal that $\mathrm{Mn}$ is energetically favored to partition to the NiAl nanoparticles by preferentially occupying the $\mathrm{Al}$ sublattice, which not only increases the driving force, but also reduces the strain energy for nucleation, thereby significantly decreasing the critical energy for formation of the NiAl nanoparticles in ferritic steels. In addition, the effects of $\mathrm{Mn}$ on the precipitation strengthening mechanisms were quantitatively evaluated in terms of chemical strengthening, coherency strengthening, modulus strengthening and order strengthening. (c) 2014 Acta Materialia Inc. Published by Elsevier Ltd. All rights reserved.
\end{abstract}

Keywords: NiAl nanoparticle; Precipitation; Microsegregation; Atom probe tomography; Mechanical property

\section{Introduction}

Ultrahigh-strength steels are highly desirable for a wide range of lightweight applications, such as in vehicles, aerospace and wind energy. Uniform precipitation of intermetallic nanoparticles has been recognized as a powerful method for strengthening steels, because high-energy antiphase boundaries must be created by moving dislocations [1-5]. The degree of strengthening so obtained is highly dependent upon the type, number density and size of the nanoparticles, and the nature of the interaction of the dislocations with the nanoparticles [6-9]. Among the various types of potential intermetallic nanoparticles to be considered for precipitation strengthening, NiAl nanoparticles constitute a class of effective strengthening phases, which have been extensively used in maraging steels, high-strength low-alloy steels and Fe-based superalloys [10-15]. NiAl possesses an ordered cubic B2 crystal structure with a high ordering energy, i.e. Ni atoms occupy the cube-corner sites and $\mathrm{Al}$ atoms occupy the body-center sites [16-18]. The lattice constant of the stoichiometric $\mathrm{NiAl}$ is $0.2887 \mathrm{~nm}$, which is close to that of body-centered cubic (bcc) Fe (0.2866 nm), such that the $\mathrm{NiAl}$ phase satisfies the lattice coherency requirement in the bcc Fe matrix [1]. Transmission electron

\footnotetext{
* Corresponding author. Tel.: +852 34427213; fax: +852 34420172; e-mail: chainliu@cityu.edu.hk
}

microscopy studies revealed that the $\mathrm{NiAl}$ nanoparticles are spherical in shape and are dispersed uniformly, with perfect coherency with the Fe matrix [19-21].

To obtain significant strengthening, it is critical to attain a high number density of $\mathrm{NiAl}$ nanoparticles distributed uniformly throughout the matrix. Approaches based on microalloying effects are particularly attractive since they can be integrated into the overall bulk alloy chemistry and additional processing steps are not usually needed. Recently, a class of Fe-Ni-Al-Mn-based ferritic steels containing a high number density of $\mathrm{NiAl}$ nanoparticles has been developed that achieves a good combination of high strength, high ductility and relatively low cost [22]. Preliminary studies suggested that Mn exhibits diffuse enrichment in the NiAl nanoparticles. However, the underlying mechanisms governing the Mn partitioning and the critical role of $\mathrm{Mn}$ in the formation of $\mathrm{NiAl}$ nanoparticles are not clear at the present time. In addition, from the metallurgical point of view, $\mathrm{Mn}$ is one of the most important bearing elements in steels [23,24], and is commonly used to reduce the brittleness by combining impurities and to remove excessive oxygen from molten steels [25]. Therefore, it is both scientifically and technically important to understand the role of $\mathrm{Mn}$ in the nanoscale precipitation of $\mathrm{NiAl}$ nanoparticles in steels.

The aim of this paper was to elucidate the basic mechanisms involved in the formation of ordered NiAl nanoparticles in ferritic steels. In particular, the effects of $\mathrm{Mn}$ 
partitioning on the nanoscale precipitation mechanisms and mechanical properties of the $\mathrm{Fe}-\mathrm{Ni}-\mathrm{Al}-\mathrm{Mn}$ model alloys were thoroughly investigated. This alloy system allows one to gain insights into the basic mechanisms and to exclude possible synergistic effects of other alloying elements. Special attention was paid to the atomic-scale partitioning and sublattice occupancy of $\mathrm{Mn}$ in the B2/bcc alloy system, as well as to its critical role in the formation of $\mathrm{NiAl}$ nanoparticles in ferritic steels.

\section{Experimental}

Four alloys, with compositions of $\mathrm{Fe}-5 \mathrm{Ni}-1 \mathrm{Al}, \mathrm{Fe}-5 \mathrm{Ni}-$ 1Al-3Mn, $\mathrm{Fe}-5 \mathrm{Ni}-3 \mathrm{Mn}$ and $\mathrm{Fe}-1 \mathrm{Al}-3 \mathrm{Mn}$ (wt.\%), were prepared by arc-melting a mixture of commercially pure metals (purity $>99.8$ wt.\%) in a Ti-gettered high-purity argon atmosphere. The ingots were remelted five times to ensure chemical homogeneity. The melted alloys were then drop-cast into a copper mold with dimensions of $50 \times 15 \times 3 \mathrm{~mm}$. The resulting plates were cold rolled by multiple passes with a total reduction of $\sim 66 \%$ and solution-treated for $30 \mathrm{~min}$ at $900{ }^{\circ} \mathrm{C}$, followed by water quenching and then aging isothermally at $550{ }^{\circ} \mathrm{C}$ for various periods of time up to $512 \mathrm{~h}$.

Hardness measurements were conducted using a Vickers hardness tester with a load of $2 \mathrm{~N}$ for $15 \mathrm{~s}$, and for each specimen, at least eight indents were measured to obtain an average value. Tensile samples with a cross-section of $3.2 \times 1 \mathrm{~mm}$ and a gauge length of $12.5 \mathrm{~mm}$ were cut by electrodischarge machining, and ground carefully on each side with $\mathrm{SiC}$ papers to 4000 grit. Tensile tests along the rolling direction of the samples were conducted on an MTS tensile testing machine at a strain rate of $10^{-3} \mathrm{~s}^{-1}$. The yield strength was determined with the $0.2 \%$ offset plastic strain method. Fracture surfaces were examined by scanning electron microscopy (SEM).

Sections of the heat-treated samples perpendicular to the rolling direction were polished to a final surface finish of $0.05 \mu \mathrm{m}$ using standard mechanical polishing procedures. The samples were etched for approximately 10-30 s with a 2 vol. $\%$ Nital solution, allowing for observation of the grain structures via SEM. The grain size was measured from micrographs using the conventional mean-linearintercept method.

The needle-shaped specimens required for atom probe tomography (APT) were fabricated by a combination of standard electropolishing methods followed by annular milling in a FEI Nova 200 focused ion beam/scanning electron microscope [26]. The APT characterizations were performed in a CAMECA Instruments LEAP 4000X HR local electrode atom probe. The specimens were analyzed in voltage mode, with a specimen temperature of $50 \mathrm{~K}$, a pulse repetition rate of $200 \mathrm{kHz}$, a pulse fraction of 0.2 and an ion collection rate of between $0.5 \%$ and $1 \%$ ions per field evaporation pulse. Imago Visualization and Analysis Software version 3.6.6 was used for three-dimensional reconstructions, composition analyses and the creation of isoconcentration surfaces.

Phase fractions and elemental compositions in thermodynamic equilibrium were calculated using the software Thermo-Calc 3.0.1, together with an Fe-based database (TCFE7) and an Ni-based database (TTNI8). First-principles calculations were based on the density functional theory implemented in the Vienna ab initio Simulation Package [27]. Projector-augmented wave potential and the Perdew-Burke-Ernzerhof generalized gradient approximation were used to describe the Coulomb interaction of ion cores with the valence electrons and the electronic exchange, respectively [28]. Three-dimensional 54-atom periodic supercells with $3 \times 3 \times 3$ unit cells were used to determine the total energy, with a plane-wave energy cutoff of $400 \mathrm{eV}$ and $3 \times 3 \times 3 \Gamma$-centered Monkhorst-Pack grids. Equilibrium cell volumes and all internal atomic positions of the supercells were fully relaxed until convergence with the total energy tolerance of $10^{-4} \mathrm{eV}$.

\section{Results}

\subsection{Mechanical properties}

The microhardness of the $\mathrm{Fe}-5 \mathrm{Ni}-1 \mathrm{Al}, \mathrm{Fe}-5 \mathrm{Ni}-1 \mathrm{Al}-$ $3 \mathrm{Mn}, \mathrm{Fe}-5 \mathrm{Ni}-3 \mathrm{Mn}$ and $\mathrm{Fe}-1 \mathrm{Al}-3 \mathrm{Mn}$ alloys is shown in Fig. 1 as a function of aging time at $550{ }^{\circ} \mathrm{C}$. The hardness of the $\mathrm{Fe}-5 \mathrm{Ni}-1 \mathrm{Al}$ alloy increases slightly from $\sim 200$ to $\sim 210 \mathrm{HV}$ during the first $30 \mathrm{~min}$ aging period and gradually reaches peak values of $\sim 260 \mathrm{HV}$ at an aging time of $10 \mathrm{~h}$. The hardness plateau lasts for more than $100 \mathrm{~h}$, then decreases with further increasing aging time due to an overaging effect. By adding 3 wt.\% Mn, the hardness of the asquenched sample reaches $\sim 280 \mathrm{HV}$, which is mainly due to the solid solution hardening and grain-size refinement induced by $\mathrm{Mn}$. Upon aging, the $\mathrm{Fe}-5 \mathrm{Ni}-1 \mathrm{Al}-3 \mathrm{Mn}$ alloy exhibits a dramatic increase in hardness to peak values of $\sim 460 \mathrm{HV}$ after $2 \mathrm{~h}$ aging, resulting in a pronounced increase in hardness $(\sim 180 \mathrm{HV})$ as compared with the asquenched sample. The above hardness measurements demonstrate that Mn significantly enhances the age-hardening response in the peak hardening conditions (by a factor of 3). In addition, to obtain an understanding of the interactions between the alloying elements, the $\mathrm{Fe}-5 \mathrm{Ni}-3 \mathrm{Mn}$ and $\mathrm{Fe}-1 \mathrm{Al}-3 \mathrm{Mn}$ alloys were tested for comparison. The hardnesses of these two alloys exhibit no appreciable changes upon aging, suggesting that precipitation hardening does not occur for Al-free and Ni-free alloys under these aging conditions.

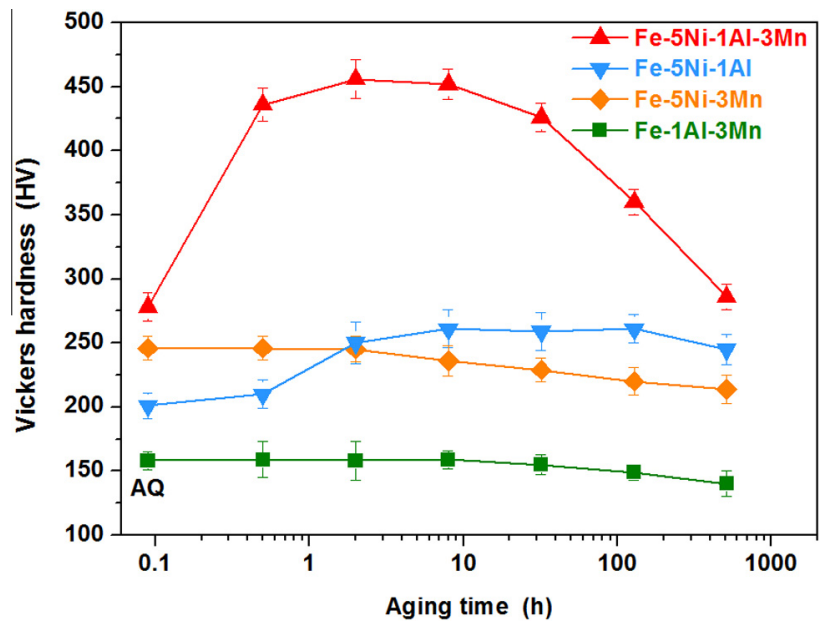

Fig. 1. Hardness as a function of aging time for the $\mathrm{Fe}-5 \mathrm{Ni}-1 \mathrm{Al}, \mathrm{Fe}-$ 5Ni-1Al-3Mn, $\mathrm{Fe}-5 \mathrm{Ni}-3 \mathrm{Mn}$ and $\mathrm{Fe}-1 \mathrm{Al}-3 \mathrm{Mn}$ alloys. 
Room-temperature tensile tests were performed to further investigate the effects of $\mathrm{Mn}$ on the mechanical properties of the alloys in the as-quenched and aged conditions. The resulting engineering stress-strain curves are presented in Fig. 2, and the yield strength, ultimate tensile strength, elongation-to-failure and reduction in area are summarized in Table 1 . In the as-quenched condition, the $\mathrm{Fe}-5 \mathrm{Ni}-1 \mathrm{Al}$ alloy shows a yield strength of $\sim 425 \mathrm{MPa}$ and an ultimate tensile strength of $\sim 525 \mathrm{MPa}$. After aging for $2 \mathrm{~h}$, both the yield strength and the ultimate tensile strength show an incremental increase of $\sim 130 \mathrm{MPa}$, together with a small loss of elongation-to-failure, from $24 \%$ to $21 \%$. In comparison, significant strengthening resulting from the aging treatment is observed in the $\mathrm{Fe}-5 \mathrm{Ni}-1 \mathrm{Al}-3 \mathrm{Mn}$ alloy. The yield strength increases dramatically from $\sim 685 \mathrm{MPa}$ in the as-quenched condition to $1225 \mathrm{MPa}$ in the $2 \mathrm{~h}$ aged condition, i.e. an increase of $\sim 540 \mathrm{MPa}$ in yield strength. Along with the improved strength, there is a slight reduction in the elongation-to-failure, but the samples are still very ductile, with an elongation-to-failure of $\sim 14 \%$ and a reduction in area of $\sim 52 \%$. Thus, the $\mathrm{Fe}-5 \mathrm{Ni}-1 \mathrm{Al}-3 \mathrm{Mn}$ alloy exhibits a good combination of high strength and high ductility. For the Al-free and Ni-free alloys (Fig. 2b), the yield strength does not show any obvious changes
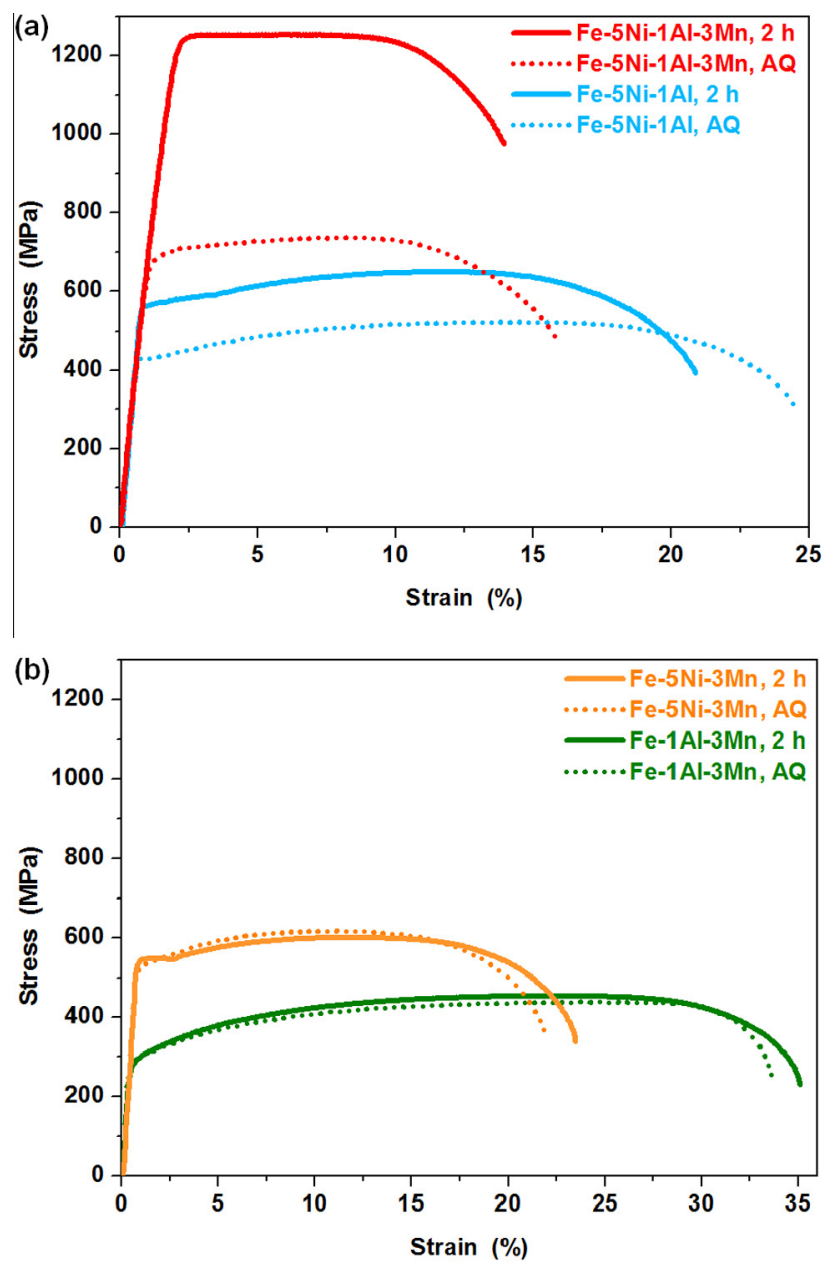

Fig. 2. Room-temperature tensile stress-strain curves for the asquenched and aged alloys: (a) $\mathrm{Fe}-5 \mathrm{Ni}-1 \mathrm{Al}$ and $\mathrm{Fe}-5 \mathrm{Ni}-1 \mathrm{Al}-3 \mathrm{Mn}$; (b) $\mathrm{Fe}-5 \mathrm{Ni}-3 \mathrm{Mn}$ and $\mathrm{Fe}-1 \mathrm{Al}-3 \mathrm{Mn}$.
Table 1. The yield strength (YS), ultimate tensile strength (UTS), elongation-to-failure (EL) and reduction in area (RA) for the asquenched (AQ) and $2 \mathrm{~h}$ aged alloys.

\begin{tabular}{lccll}
\hline & $\begin{array}{l}\text { YS } \\
(\mathrm{MPa})\end{array}$ & $\begin{array}{l}\text { UTS } \\
(\mathrm{MPa})\end{array}$ & $\begin{array}{l}\text { EL } \\
(\%)\end{array}$ & $\begin{array}{l}\text { RA } \\
(\%)\end{array}$ \\
\hline Fe-5Ni-1Al, AQ & 425 & 525 & 24 & 90 \\
Fe-5Ni-1Al, 2 h & 558 & 651 & 21 & 87 \\
Fe-5Ni-1Al-3Mn, AQ & 685 & 737 & 16 & 69 \\
Fe-5Ni-1Al-3Mn, 2 h & 1225 & 1255 & 14 & 52 \\
Fe-5Ni-3Mn, AQ & 526 & 617 & 22 & 80 \\
Fe-5Ni-3Mn, 2 h & 537 & 604 & 24 & 79 \\
Fe-1Al-3Mn, AQ & 285 & 439 & 33 & 93 \\
Fe-1Al-3Mn, 2 h & 280 & 456 & 35 & 93 \\
\hline
\end{tabular}

after $2 \mathrm{~h}$ aging, which is consistent with the hardness measurements and further confirms that $\mathrm{Mn}$ in combination with individual $\mathrm{Ni}$ or $\mathrm{Al}$ additions does not give rise to an obvious strengthening effect.

The fracture surfaces of the $\mathrm{Fe}-5 \mathrm{Ni}-1 \mathrm{Al}$ and $\mathrm{Fe}-5 \mathrm{Ni}-$ $1 \mathrm{Al}-3 \mathrm{Mn}$ alloys in the as-quenched and $2 \mathrm{~h}$ aged conditions are shown in Fig. 3. The precipitation-hardening effects did not induce a significant change of the fracture mode, and all the as-quenched and aged samples show obvious necking and many fine dimples, a characteristic mode of ductile fracture.

\subsection{Microstructural characterization}

The microstructures of the $\mathrm{Fe}-5 \mathrm{Ni}-1 \mathrm{Al}$ and $\mathrm{Fe}-5 \mathrm{Ni}-$ $1 \mathrm{Al}-3 \mathrm{Mn}$ alloys in the as-quenched and $2 \mathrm{~h}$ aged conditions are exhibited in Fig. 4. The as-quenched $\mathrm{Fe}-5 \mathrm{Ni}-1 \mathrm{Al}$ alloy (Fig. 4a) consists of equiaxed ferrite grains with an average size of $\sim 13 \mu \mathrm{m}$. After $2 \mathrm{~h}$ aging (Fig. 4b), there are no noticeable changes in grain structure. By adding $3 \mathrm{wt} . \%$ $\mathrm{Mn}$, the average grain size of the as-quenched and aged samples (Fig. 4c and d, respectively) is substantially refined to $\sim 5 \mu \mathrm{m}$, which can be attributed to the lowering of the austenite-to-ferrite transformation temperature by the $\mathrm{Mn}$ additions. The phase equilibria of the $\mathrm{Fe}-5 \mathrm{Ni}-1 \mathrm{Al}$ and $\mathrm{Fe}-5 \mathrm{Ni}-1 \mathrm{Al}-3 \mathrm{Mn}$ alloys were calculated as a function of temperature using Thermo-Calc. The austenite-to-ferrite transformation temperatures of the $\mathrm{Fe}-5 \mathrm{Ni}-1 \mathrm{Al}$ and $\mathrm{Fe}-$ $5 \mathrm{Ni}-1 \mathrm{Al}-3 \mathrm{Mn}$ alloys are calculated to be $\sim 870^{\circ} \mathrm{C}$ and $\sim 760{ }^{\circ} \mathrm{C}$, respectively, i.e. a decrease of $\sim 110^{\circ} \mathrm{C}$ induced by $\mathrm{Mn}$. It is known that $\mathrm{Mn}$, as an austenite stabilizer, could extend the austenite region and retard the austenite-to-ferrite transformation to a lower temperature, which would lead to an increase in the driving force of grain nucleation and a decrease in the grain growth rate, thereby refining the ferrite grains [25]. Therefore, the $\mathrm{Mn}$ additions are beneficial to lowering the austenite-to-ferrite transformation temperature in the ferritic alloys, thereby refining the grain size.

\subsection{Atom probe tomography characterization}

To attain precise information about the nanoscale precipitation process, APT investigations were performed on the $\mathrm{Fe}-5 \mathrm{Ni}-1 \mathrm{Al}$ and $\mathrm{Fe}-5 \mathrm{Ni}-1 \mathrm{Al}-3 \mathrm{Mn}$ alloys in the $2 \mathrm{~h}$ aged condition. The distribution of the NiAl nanoparticles in these alloys is represented by $30 \%(\mathrm{Ni}+\mathrm{Al})$ isoconcentration surfaces, as shown in Fig. 5a and b. The two alloys with and without Mn exhibit remarkable differences in the 

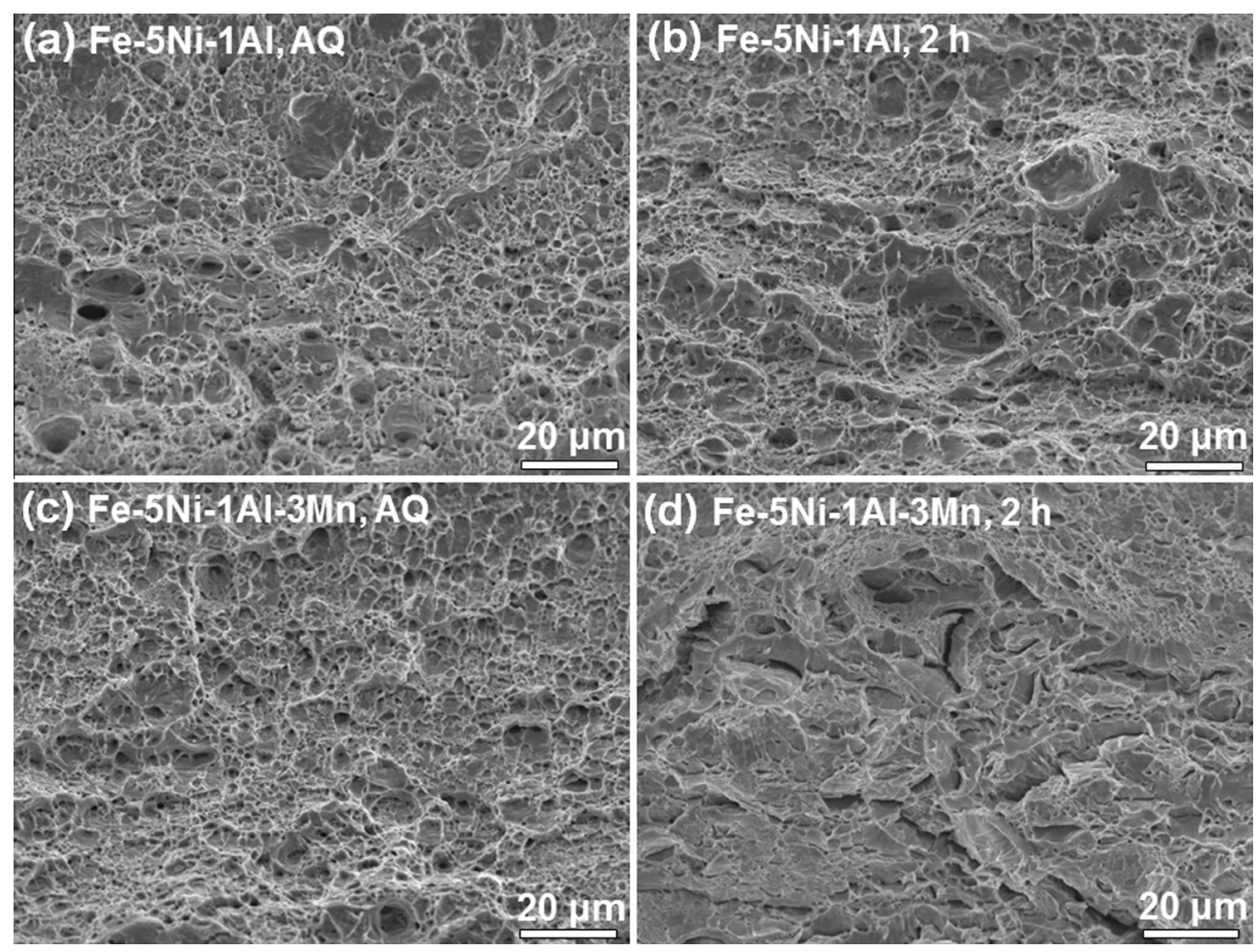

Fig. 3. Fracture surfaces of the alloys: (a) $\mathrm{Fe}-5 \mathrm{Ni}-1 \mathrm{Al}$, as-quenched; (b) $\mathrm{Fe}-5 \mathrm{Ni}-1 \mathrm{Al}, 2 \mathrm{~h}$; (c) $\mathrm{Fe}-5 \mathrm{Ni}-1 \mathrm{Al}-3 \mathrm{Mn}$, as-quenched; and (d) $5 \mathrm{Ni}-1 \mathrm{Al}-$ $3 \mathrm{Mn}, 2 \mathrm{~h}$.
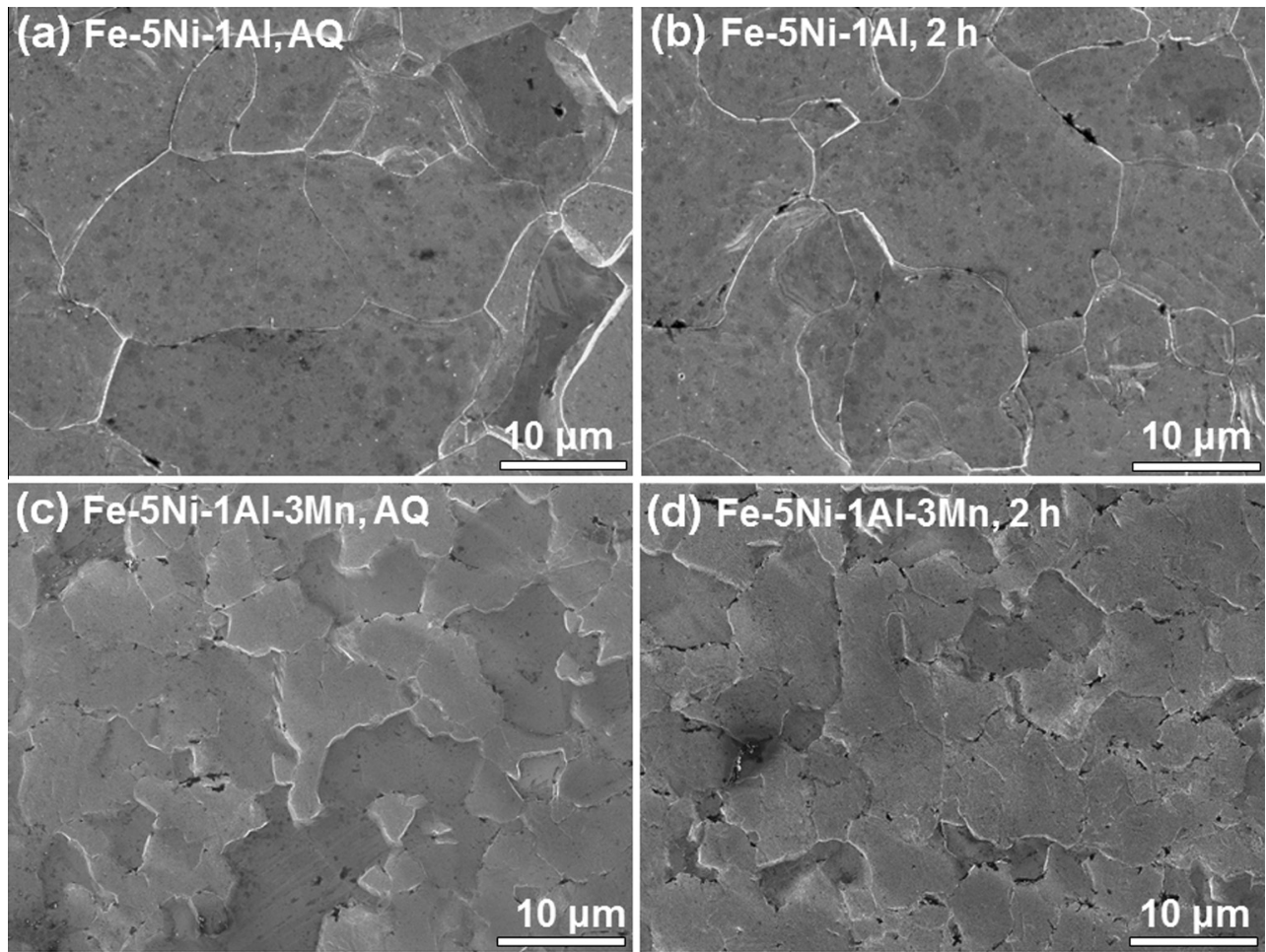

Fig. 4. Microstructures of the alloys: (a) Fe-5Ni-1Al, as-quenched; (b) Fe-5Ni-1Al, 2 h; (c) Fe-5Ni-1Al-3Mn, as-quenched; and (d) $5 \mathrm{Ni}-1 \mathrm{Al}-3 \mathrm{Mn}$, $2 \mathrm{~h}$.

distributions of the nanoparticles, especially in terms of particle size and number density, which are summarized in Fig. 5c. The number density and average radius of the
$\mathrm{NiAl}$ nanoparticles in the $\mathrm{Fe}-5 \mathrm{Ni}-1 \mathrm{Al}$ alloy (Fig. 5a), as determined from the isoconcentration surfaces, are $\sim 1.7 \times 10^{22} \mathrm{~m}^{-3}$ and $\sim 2.21 \mathrm{~nm}$, respectively. By adding 

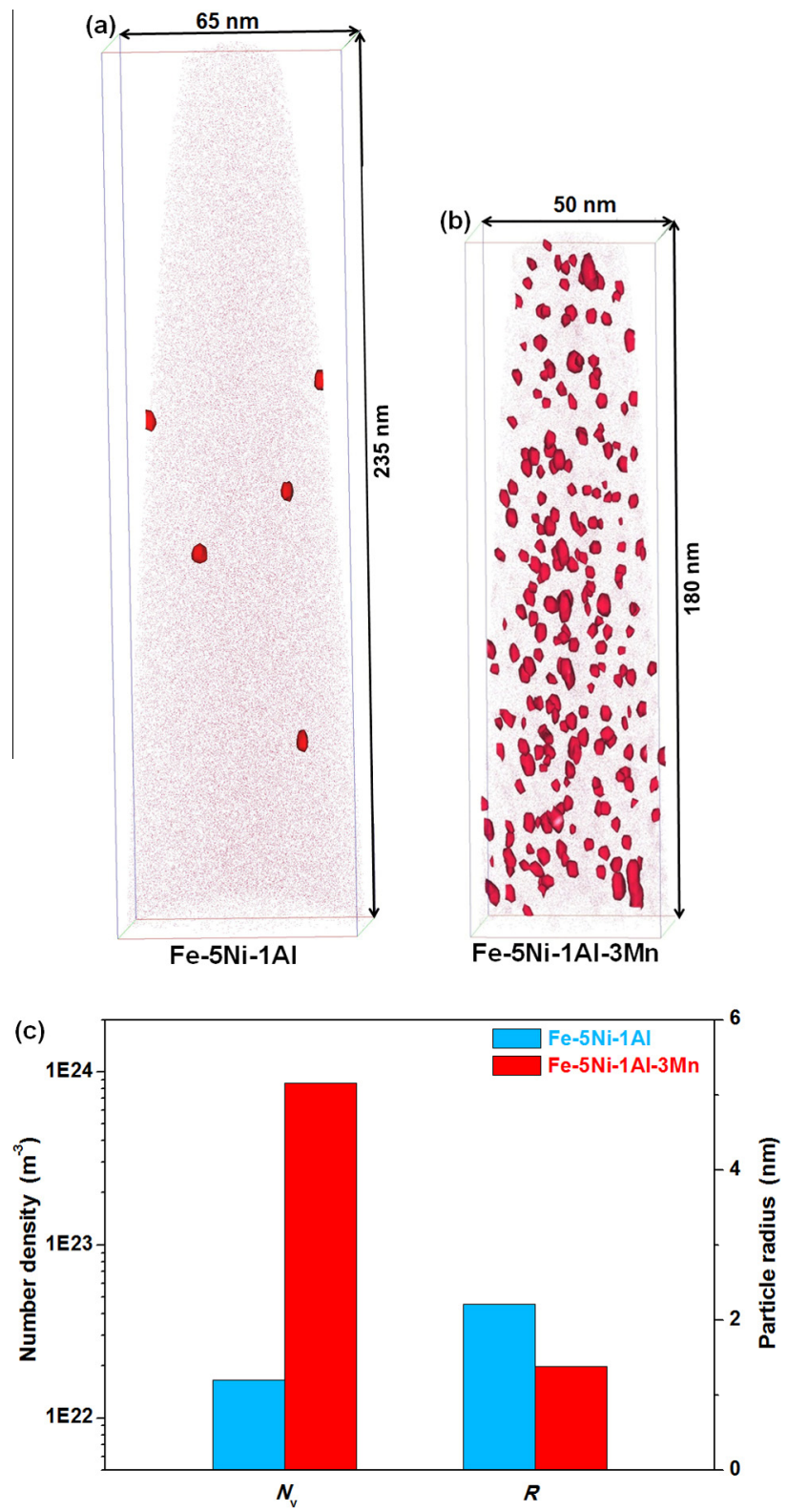

Fig. 5. $30 \%(\mathrm{Ni}+\mathrm{Al})$ concentration isosurface of the alloys aged for $2 \mathrm{~h}$ at $550{ }^{\circ} \mathrm{C}$ : (a) $\mathrm{Fe}-5 \mathrm{Ni}-1 \mathrm{Al}$; (b) $\mathrm{Fe}-5 \mathrm{Ni}-1 \mathrm{Al}-3 \mathrm{Mn}$; and (c) nanoparticle radius and number density.

3 wt.\% Mn (Fig. 5b), the number density of the nanoparticles increases dramatically, by more than 50 -fold, to $\sim 8.6 \times 10^{23} \mathrm{~m}^{-3}$, concomitant with the nanoparticle radius decreasing to $\sim 1.38 \mathrm{~nm}$.

To further understand the underlying mechanisms of how $\mathrm{Mn}$ promotes the formation of the NiAl nanoparticles, 1 -nm-thick atom maps through the centers of the nanoparticles in which the relative positions and extents of the Al (cyan), Ni (red) and $\mathrm{Mn}$ (blue) atoms are indicated for the Mn-free and Mn-containing alloys are shown in Fig. 6a and b, respectively. It is evident that $\mathrm{Ni}$ and $\mathrm{Al}$ exhibit local enrichment in the $\sim 3 \mathrm{~nm}$ nanoparticles in both alloys. What is more interesting, and potentially relevant to an understanding of the formation mechanisms of the ordered NiAl nanoparticles in the bcc Fe matrix, is that a strong partitioning of $\mathrm{Mn}$ to the NiAl nanoparticles is observed in the Mn-containing alloy. Proximity histograms were constructed based on the 30 at. $\%(\mathrm{Ni}+\mathrm{Al})$ isoconcentration surface and are shown in Fig. $6 \mathrm{c}$ and $\mathrm{d}$ for the $\mathrm{Fe}-$ $5 \mathrm{Ni}-1 \mathrm{Al}$ and $\mathrm{Fe}-5 \mathrm{Ni}-1 \mathrm{Al}-3 \mathrm{Mn}$ alloys, respectively. In the $\mathrm{Fe}-5 \mathrm{Ni}-1 \mathrm{Al}$ alloy, the partitioning of $\mathrm{Fe}$ to the matrix and the partitioning of $\mathrm{Ni}$ and $\mathrm{Al}$ to the $\mathrm{NiAl}$ nanoparticles are clearly evident in Fig. 6c. However, the nanoparticles are not pure NiAl but contain limited amounts of Fe, which may facilitate the stability of the coherent $\mathrm{NiAl}$ nanoparticles [14]. In the Mn-containing alloy, $\mathrm{Fe}-5 \mathrm{Ni}-1 \mathrm{Al}-3 \mathrm{Mn}$ (Fig. 6d), Ni exhibits a higher than stoichiometric degree of partitioning as compared with $\mathrm{Al}$ in the $\mathrm{NiAl}$ nanoparticles. In addition, $\mathrm{Mn}$ shows a preferential partitioning to the $\mathrm{NiAl}$ nanoparticles, with a maximum $\mathrm{Mn}$ concentration of $\sim 10$ at. $\%$ in the nanoparticle core. The atomic ratio of $\mathrm{Ni} / \mathrm{Al}$ in the nanoparticles is also not stoichiometric, and the average composition of these nanoparticles in the Mn-containing alloy can be regarded as $34.1 \% \mathrm{Ni}-21.8 \%$ Al-8.4\% Mn-35.7\% Fe.

\section{Discussion}

\subsection{Mechanisms for the preferential partitioning of Mn to NiAl nanoparticles}

Generally, element partitioning in multicomponent alloys is governed by driving forces arising from the chemical interactions and compatibilities between the constituents [29]. The higher the level of chemical interaction and compatibility of an element with a phase, the greater the extent of element partitioning to the phase should be. In this study, the mechanisms for the preferential partitioning of $\mathrm{Mn}$ to the $\mathrm{NiAl}$ nanoparticles are analyzed from these two aspects.

First, the preferential partitioning of $\mathrm{Mn}$ to the NiAl nanoparticles can be explained by the chemical interactions between the constituent elements $\mathrm{Mn}, \mathrm{Fe}, \mathrm{Ni}$ and $\mathrm{Al}$. Mixing enthalpy is an important indicator of chemical interactions between constituent elements in solids [29]. Ni has a large negative mixing enthalpy with $\mathrm{Al}\left(-22 \mathrm{~kJ} \mathrm{~mol}^{-1}\right)$ [30], indicating a high level of interaction between $\mathrm{Ni}$ and $\mathrm{Al}$, as evidenced by the formation of the NiAl phase in the $\mathrm{Fe}-5 \mathrm{Ni}-1 \mathrm{Al}$ alloy (Fig. 5a). The mixing enthalpy for the $\mathrm{Fe}-\mathrm{Mn}$ pair is zero, implying a nearly non-interacting solid solution, whereas the values for both the Al-Mn and $\mathrm{Ni}-\mathrm{Mn}$ pairs are quite large and negative (i.e. -19 and $-8 \mathrm{~kJ} \mathrm{~mol}^{-1}$, respectively) [30]. Therefore, the chemical interaction between $\mathrm{Ni}-\mathrm{Al}-\mathrm{Mn}$ is significantly greater than that between $\mathrm{Fe}$ and $\mathrm{Mn}$, which favors the partitioning of $\mathrm{Mn}$ to the NiAl phase.

Secondly, the enrichment of Mn in the NiAl nanoparticles and its depletion in the ferrite matrix can be explained by the chemical compatibility of $\mathrm{Mn}$ with the $\mathrm{Ni}$-Al-rich nanoparticles and the Fe-Ni-rich ferrite matrix. Thermodynamic calculations were performed using the Thermo-Calc software to assess the phase equilibrium in the $\mathrm{Fe}-\mathrm{Ni}-\mathrm{Mn}$ and $\mathrm{Ni}-\mathrm{Al}-\mathrm{Mn}$ alloy systems. The calculated isothermal sections of the $\mathrm{Fe}-\mathrm{Ni}-\mathrm{Mn}$ and $\mathrm{Ni}-\mathrm{Al}-\mathrm{Mn}$ ternary phase diagrams at the aging temperature of $550^{\circ} \mathrm{C}$ are presented in Fig. 7a and $\mathrm{b}$, respectively. In the $\mathrm{Fe}-\mathrm{Ni}-\mathrm{Mn}$ system (Fig. 7a), the solubility of $\mathrm{Mn}$ in $\alpha-\mathrm{Fe}$ is quite low, with a maximum solubility of $\sim 3.5$ at.\%. With a small amount of $\mathrm{Ni}$, its solubility in $\alpha-\mathrm{Fe}$ is even further reduced. In 
(a)

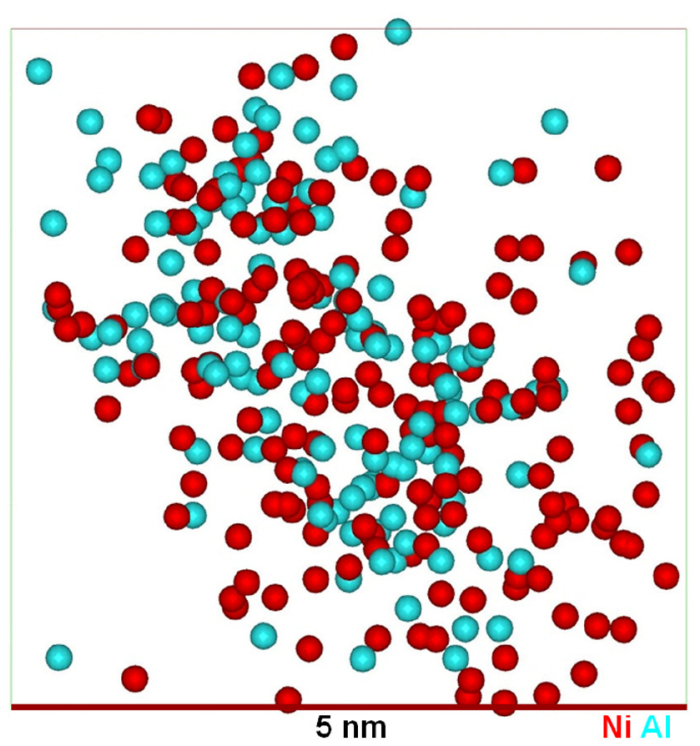

(c) 100

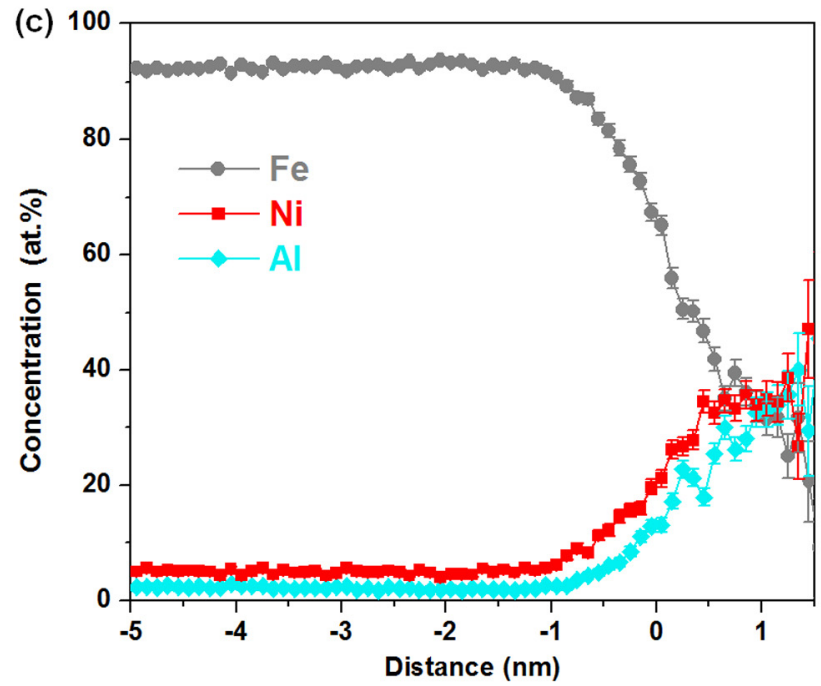

(b)

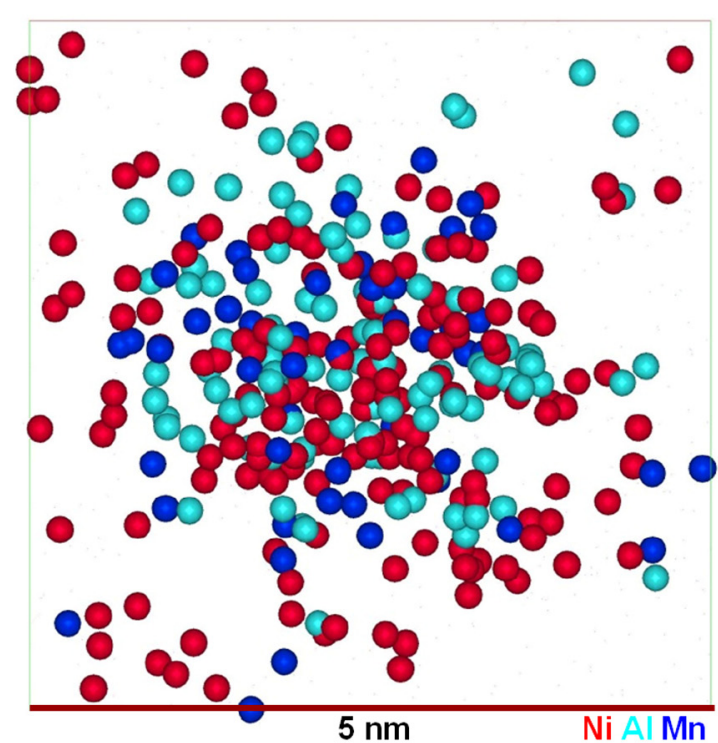

(d) 100

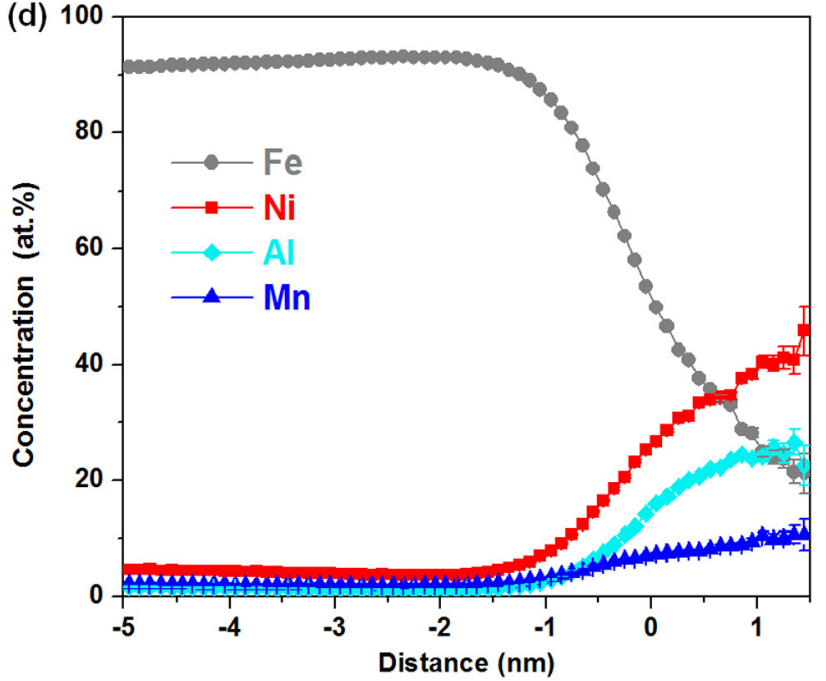

Fig. 6. 1-nm-thick atom maps showing the $\mathrm{Al}, \mathrm{Ni}$ and $\mathrm{Mn}$ atoms through the centers of NiAl nanoparticles and proximity histogram: (a, c) Fe-5Ni$1 \mathrm{Al}$; (b, d) $\mathrm{Fe}-5 \mathrm{Ni}-1 \mathrm{Al}-3 \mathrm{Mn}$.

comparison, in the $\mathrm{Ni}-\mathrm{Al}-\mathrm{Mn}$ system, a large single-phase region of the $\mathrm{NiAl}$ phase that could dissolve more than 20 at. $\% \mathrm{Mn}$ is evident. Thus, the solubility of $\mathrm{Mn}$ in the $\mathrm{NiAl}$ phase is significantly greater than that in the ferrite phase, indicating a higher chemical compatibility of $\mathrm{Mn}$ with the $\mathrm{NiAl}$ phase than with the ferrite phase. Based on the above analyses, the greater chemical interaction and compatibility of $\mathrm{Mn}$ with the $\mathrm{NiAl}$ phase, as compared with that with the ferrite phase, thermodynamically favors the preferential partitioning of $\mathrm{Mn}$ to the $\mathrm{NiAl}$ nanoparticles, resulting in the enrichment of $\mathrm{Mn}$ in the NiAl nanoparticles and its depletion in the ferrite matrix.

\subsection{Sublattice occupancies of Mn in NiAl nanoparticles}

Previous studies had indicated that Mn could occupy both the $\mathrm{Ni}$ and $\mathrm{Al}$ sublattices in $\mathrm{B} 2$-ordered NiAl intermetallic alloys, depending on the alloy composition [31,32]. The atomistic knowledge of the occupancy of $\mathrm{Mn}$ in the sublattices of the ordered $\mathrm{NiAl}$ nanoparticles is essential for the fundamental understanding of the effects of the
Mn partitioning on the nanoscale precipitation mechanisms, as the atomic structure and ordering both play an important role in controlling the formation and stabilization of nanoparticles [33-36]. To explore the Mn sublattice occupancy in the complex nanoparticles, first-principles calculations were performed in 54-atom supercells comprising $18 \mathrm{Ni}, 12 \mathrm{Al}, 4 \mathrm{Mn}$ and $20 \mathrm{Fe}$ atoms, where the atomic ratios between the $\mathrm{Ni}, \mathrm{Al}, \mathrm{Mn}$ and $\mathrm{Fe}$ are based on the nanoparticle composition determined by APT. Five B2ordered NiAl-type models with different Mn substitutional sites were constructed: (1) B2- $\left(\mathrm{Ni}_{18} \mathrm{Mn}_{4} \mathrm{Fe}_{5}\right)\left(\mathrm{Al}_{12} \mathrm{Fe}_{15}\right)$, with all of the $\mathrm{Mn}$ occupying the $\mathrm{Ni}$ site; (2) $\mathrm{B} 2-\left(\mathrm{Ni}_{18} \mathrm{Mn}_{3-}\right.$ $\left.\mathrm{Fe}_{6}\right)\left(\mathrm{Al}_{12} \mathrm{Mn}_{1} \mathrm{Fe}_{14}\right)$, with $25 \%$ of the Mn occupying the $\mathrm{Al}$ site and the remaindering occupying the Ni site; (3) B2$\left(\mathrm{Ni}_{18} \mathrm{Mn}_{2} \mathrm{Fe}_{7}\right)\left(\mathrm{Al}_{12} \mathrm{Mn}_{2} \mathrm{Fe}_{13}\right)$, with half of the Mn occupying the $\mathrm{Al}$ site and the other half occupying the $\mathrm{Ni}$ site; (4) B2-( $\left(\mathrm{Ni}_{18} \mathrm{Mn}_{1} \mathrm{Fe}_{8}\right)\left(\mathrm{Al}_{12} \mathrm{Mn}_{3} \mathrm{Fe}_{12}\right)$ with $75 \%$ of the $\mathrm{Mn}$ occupying the $\mathrm{Al}$ site and the remaindering occupying the $\mathrm{Ni}$ site; and (5) $\mathrm{B} 2-\left(\mathrm{Ni}_{18} \mathrm{Fe}_{9}\right)\left(\mathrm{Al}_{12} \mathrm{Mn}_{4} \mathrm{Fe}_{11}\right)$, with all of the $\mathrm{Mn}$ occupying the $\mathrm{Al}$ site. The formation energies of the ordered nanoparticles with different $\mathrm{Mn}$ sublattice 

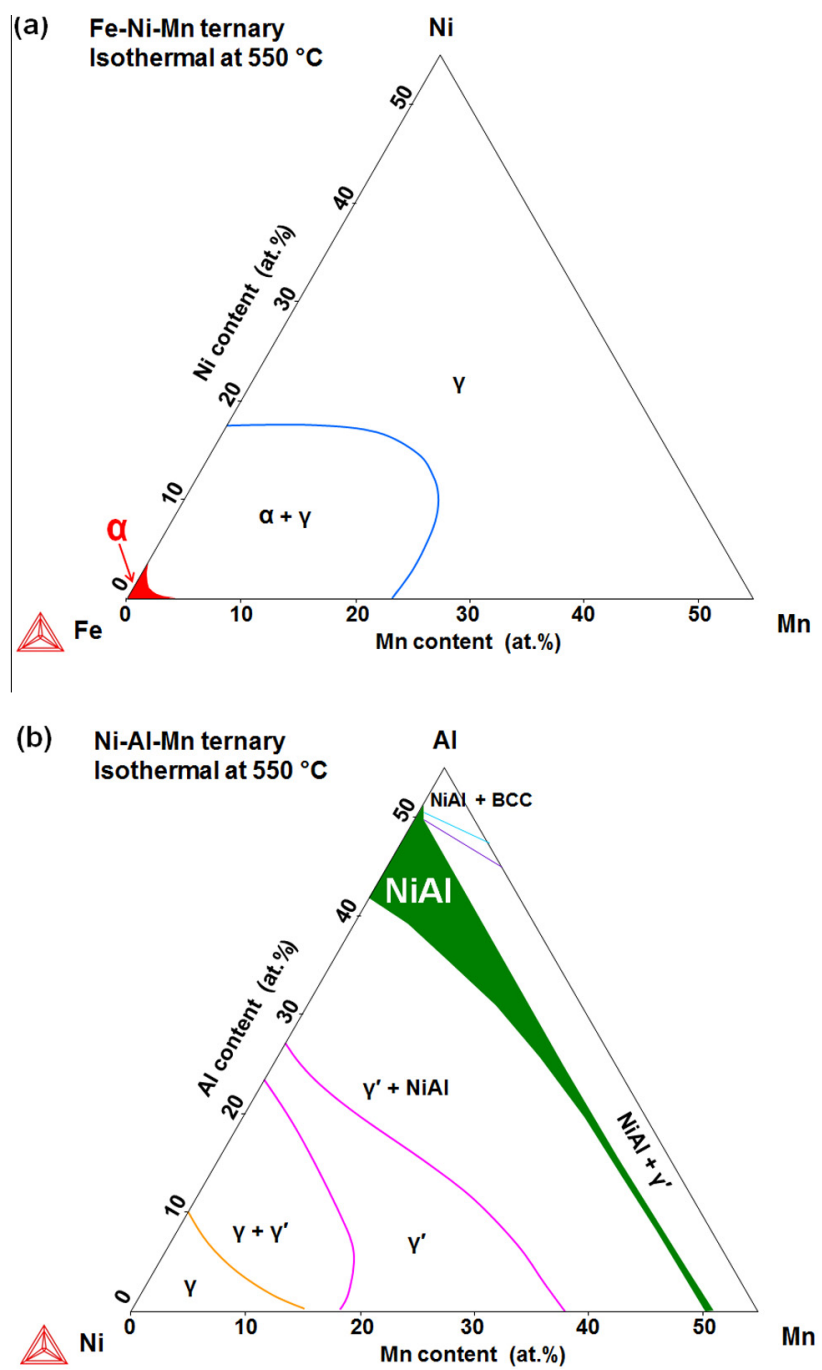

Fig. 7. Isothermal sections of the ternary phase diagrams at $550{ }^{\circ} \mathrm{C}$ : (a) $\mathrm{Fe}-\mathrm{Ni}-\mathrm{Mn}$ and (b) Ni-Al-Mn.

occupancies were calculated according to the following equation:

$$
\begin{aligned}
E_{\text {formation }}= & \left(E_{\left(\mathrm{Ni}_{18} \mathrm{Mn}_{\mathrm{x}} \mathrm{Fe}_{9-x}\right)\left(\mathrm{Al}_{12} \mathrm{Mn}_{4-x} \mathrm{Fe}_{11+x}\right)}-18 \mu_{\mathrm{Ni}}-12 \mu_{\mathrm{Al}}\right. \\
& \left.-4 \mu_{\mathrm{Mn}}-20 \mu_{\mathrm{Fe}}\right) / 54
\end{aligned}
$$

where $E_{\left(\mathrm{Ni}_{18} \mathrm{Mn}_{x} \mathrm{Fe}_{9-x}\right)\left(\mathrm{Al}_{12} \mathrm{Mn}_{4-x} \mathrm{Fe}_{11+x}\right)}$ is the total energies of the 54-atom supercells with different Mn sublattice occupancies, $x=0,1,2,3$ and 4, representing the number of $\mathrm{Mn}$ atoms in the $\mathrm{Ni}$ site of the 54-atom supercells, and $\mu_{\mathrm{Ni}}$, $\mu_{\mathrm{Al}}, \mu_{\mathrm{Mn}}$ and $\mu_{\mathrm{Fe}}$ are the chemical potentials of the $\mathrm{Ni}$, Al, $\mathrm{Mn}$ and $\mathrm{Fe}$ elements in the bcc solid solution, respectively. Based on the calculated total energies and chemical potentials in the 54-atom supercells, the formation energies of the five structures with different Mn substitution sites were calculated and are shown in Fig. 8. For $\left(\mathrm{Ni}_{18} \mathrm{Mn}_{4}\right.$ $\left.\mathrm{Fe}_{5}\right)\left(\mathrm{Al}_{12} \mathrm{Fe}_{15}\right)$, with all of the Mn occupying the Ni site (model 1), the formation energy is determined to be $-0.0861 \mathrm{eV}$ atom $^{-1}$. As more Mn occupies the Al site, the formation energy decreases gradually. When all of the $\mathrm{Mn}$ occupies the Al site (model 5), the formation energy of $\left(\mathrm{Ni}_{18} \mathrm{Fe}_{9}\right)\left(\mathrm{Al}_{12} \mathrm{Mn}_{4} \mathrm{Fe}_{11}\right)$ decreases to $-0.1219 \mathrm{eV}$ atom $^{-1}$. The above calculations show that the structure with all of the Mn occupying the Al site is energetically

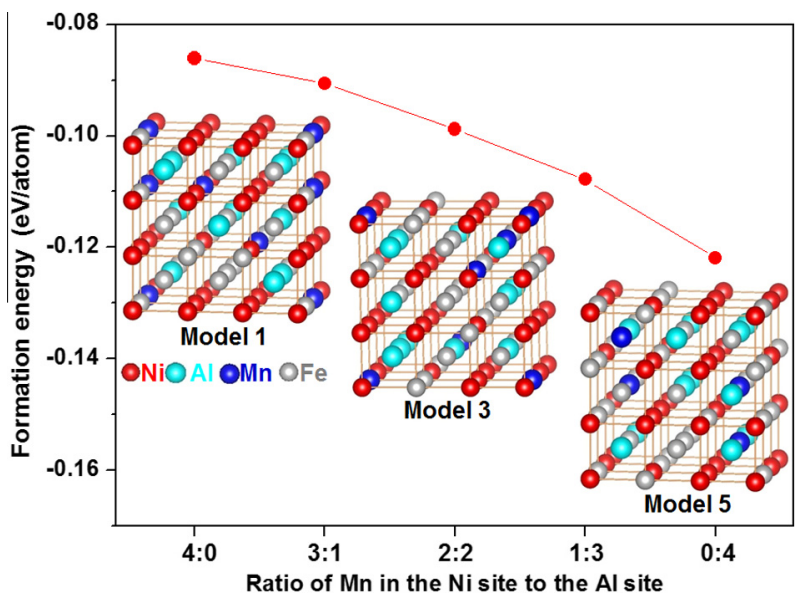

Fig. 8. Calculated formation energies of the structures with different sublattice occupancies. The insets are atom positions of $\mathrm{Ni}, \mathrm{Al}, \mathrm{Mn}$ and $\mathrm{Fe}$ in the representative models 1,3 and 5.

favored over that with all or partial Mn occupying the $\mathrm{Ni}$ sublattice, implying that $\mathrm{Mn}$ is essentially substitutional for the Al site in the NiAl-type nanoparticles.

\subsection{Origins of the Mn-enhanced precipitation of NiAl nanoparticles}

We now consider the cause of the higher number density of NiAl nanoparticles in the Mn-containing alloys. According to the classical nucleation theory, the nucleation rate giving the number of nanoparticles per unit time per unit volume is expressed by [37]

$\left.\frac{d N}{d t}\right|_{\text {nucleation }} \propto \exp \left(\frac{-\Delta G^{*}}{k_{B} T}\right)$

where $k_{B}$ is Boltzmann's constant, $T$ is the temperature and $\Delta G^{*}$ is the critical energy for nucleation, which is described by [37]

$\Delta G^{*}=\frac{16 \pi \gamma^{3}}{3\left(\Delta G_{V}-\Delta G_{\varepsilon}\right)^{2}}$

where $\gamma$ is the interfacial energy between the nanoparticles and the matrix, $\Delta G_{V}$ is the chemical driving force for nucleation and $\Delta G_{\varepsilon}$ is the elastic strain energy. The beneficial effects of the Mn partitioning on promoting the formation of the NiAl nanoparticles can be discussed in terms of the chemical driving force and the elastic strain energy for nucleation. First, the partial substitution of $\mathrm{Mn}$ for $\mathrm{Al}$ in the NiAl nanoparticles is equivalent to increasing the total concentration of the nanoparticle-forming elements. As a result, the matrix supersaturation of $\mathrm{Ni}, \mathrm{Al}$ and $\mathrm{Mn}$ in the $\mathrm{Fe}-5 \mathrm{Ni}-1 \mathrm{Al}-3 \mathrm{Mn}$ alloy is higher as compared with that of $\mathrm{Ni}$ and $\mathrm{Al}$ in the $\mathrm{Fe}-5 \mathrm{Ni}-1 \mathrm{Al}$ alloy, and this results in an increase in chemical driving force for nucleation of the nanoparticles. Second, the partial substitution of Mn for $\mathrm{Al}$ in the $\mathrm{NiAl}$ nanoparticles decreases the lattice mismatch between the nanoparticles and the matrix. Because the lattice constant of $\mathrm{B} 2-\mathrm{NiAl}$ is larger than that of the bcc Fe, the formation of B2-NiAl nanoparticles would create an elastic misfit strain at the interface. It is known that the atomic radius of $\mathrm{Mn}(1.28 \AA)$ is significantly smaller than that of $\mathrm{Al}(1.43 \AA)$ and larger than that of $\mathrm{Ni}(1.22 \AA)$ [17]. The partial substitution of Mn for Al would decrease 
the lattice parameter of the $\mathrm{NiAl}$ nucleus, thereby reducing the lattice misfit strain energy for nucleation of the nanoparticles. As a result of the increased chemical driving force and the decreased strain energy, the critical energy for the nucleation of the NiAl nanoparticles is significantly reduced, leading to an increased nucleation rate in the Mn-containing alloy system. Consequently, the particle number density in the Mn-containing alloy is dramatically increased as compared with that in the Mn-free alloy (see Fig. 5).

\subsection{Effects of Mn additions on precipitation strengthening}

The mechanical results reveal that Mn additions significantly enhance the precipitation strengthening response of the alloys, which is technically important for the design of low-cost high-strength steels. To gain a basic insight into the composition-microstructure-property relationship in $\mathrm{NiAl}$ nanoparticle-strengthened steels, it is necessary for us to model the strengthening mechanisms of the nanoparticles with and without the Mn partitioning.

The interaction mechanism between the dislocations and the NiAl nanoparticles can be either Orowan looping or particle shearing, depending on the particle size and properties. Considering that the average particle radii $(2.21$ and $1.38 \mathrm{~nm}$ for the $\mathrm{Fe}-5 \mathrm{Ni}-1 \mathrm{Al}$ and $\mathrm{Fe}-5 \mathrm{Ni}-1 \mathrm{Al}-3 \mathrm{Mn}$ alloys, respectively) are smaller than the critical radius for Orowan looping, the gliding dislocations would shear the $\mathrm{NiAl}$ nanoparticles rather than loop them [38]. It is known that, when nanoparticles are sheared by the moving dislocations, the alloy flow stress depends on the details of the interactions between the dislocations and the nanoparticles. In the present study, the major factors which could contribute to precipitation strengthening are chemical strengthening $\left(\Delta \sigma_{\text {chemical }}\right)$, coherency strengthening ( $\left.\Delta \sigma_{\text {coherency }}\right)$, modulus strengthening $\left(\Delta \sigma_{\text {modulus }}\right)$ and order strengthening $\left(\Delta \sigma_{\text {order }}\right)$.

First, when a nanoparticle is sheared by a dislocation, chemical strengthening occurs due to the production of new particle-matrix interfacial areas, as given by [39]

$\Delta \sigma_{\text {chemical }}=\frac{2 M}{b L T^{1 / 2}} \cdot\left(\gamma_{\text {interfacial }} b\right)^{3 / 2}$

where $M=3$ is the Taylor factor, $b=0.25 \mathrm{~nm}$ is the Burgers vector in the matrix, $T$ is the line tension of the dislocation, usually taken to be $G b^{2} / 2[39], G=80 \mathrm{GPa}$ is the shear modulus of the matrix and $\gamma_{\text {interfacial }}=0.35 \mathrm{~J} \mathrm{~m}^{-2}$ is the interfacial energy [38]. The mean particle spacing, $L$, in the slip plane is calculated from the equation $L=0.866 /(R N)^{1 / 2}$, where $R$ and $N$ are the average nanoparticle radius and number density, respectively [39].

Second, due to the lattice coherency of the ordered NiAl nanoparticles with the ferrite matrix and volumetric misfit strains, an elastic stress field exists in the matrix surrounding the nanoparticles. The increment in yield strength due to the coherency strain associated with the nanoparticles is given by [39]

$\Delta \sigma_{\text {coherency }}=4.1 M G \varepsilon^{3 / 2} f^{1 / 2}\left(\frac{R}{b}\right)^{1 / 2}$

where $\varepsilon=2 / 3(\Delta a / a)$ is the constrained lattice parameter mismatch, with $\Delta a / a \approx 0.002$ as the lattice parameter mismatch at room temperature [19], and $f$ is the volume fraction of the $\mathrm{NiAl}$ nanoparticles, which is estimated by $f=4 / 3 \pi R^{3} N$, where $R$ and $N$ are the nanoparticle radius and number density, respectively.

Third, when a dislocation intersects a nanoparticle with a shear modulus lower than that of the matrix, modulus strengthening occurs due to the differences in dislocation line energy within the nanoparticles and the matrix. According to the Russell-Brown model, the strength increased by the modulus difference is described by [40]

$\Delta \sigma_{\text {modulus }}=M \frac{G b}{L}\left[1-\left(\frac{E_{p}}{E_{m}}\right)^{2}\right]^{\frac{3}{4}}$

where $E_{p}$ and $E_{m}$ are the dislocation line energy in the matrix and the nanoparticles, respectively. As described in more detail in Ref. [40], the ratio of $E_{p} / E_{m}$ depends on the nanoparticle radius $R$, and is calculated to be 0.987 in this study.

Fourth, when a matrix dislocation shears an ordered nanoparticle, it creates an anti-phase boundary of specific energy. The corresponding order strengthening can be estimated by [39]

$\Delta \sigma_{\text {order }}=M\left(\frac{\gamma_{a p b^{3 / 2}}}{b}\right)\left(\frac{4 r_{s} f}{\pi T}\right)^{1 / 2}$

where $r_{s}=(2 / 3)^{1 / 2} R$ is the average nanoparticle radius in the glide plane [39] and $\gamma_{a p b}=0.5 \mathrm{~J} \mathrm{~m}^{-2}$ is the average value of the NiAl anti-phase boundary energies $[38,41]$.

Using the experimental data determined by APT, the strengthening contributions from each individual mechanism are calculated as shown in Fig. 9. For alloys both with and without $\mathrm{Mn}$, the effects of chemical strengthening and coherency strengthening are relatively small. Modulus strengthening makes a substantial contribution to the increase in yield strength, showing strength increments of $\sim 27$ and $\sim 156 \mathrm{MPa}$ for the $\mathrm{Fe}-5 \mathrm{Ni}-1 \mathrm{Al}$ and $\mathrm{Fe}-5 \mathrm{Ni}-$ $1 \mathrm{Al}-3 \mathrm{Mn}$ alloys, respectively. Order strengthening is a major source of precipitation strengthening, contributing $\sim 113$ and $\sim 313 \mathrm{MPa}$ to the $\mathrm{Fe}-5 \mathrm{Ni}-1 \mathrm{Al}$ and $\mathrm{Fe}-5 \mathrm{Ni}-$ 1Al-3Mn alloys, respectively. On the reasonable assumption that the contributions due to all these factors are additive, the overall precipitation strengthenings are determined to be $\sim 150$ and $\sim 505 \mathrm{MPa}$ for the $\mathrm{Fe}-5 \mathrm{Ni}-1 \mathrm{Al}$ and $\mathrm{Fe}-5 \mathrm{Ni}-1 \mathrm{Al}-3 \mathrm{Mn}$ alloys, respectively, which are close to

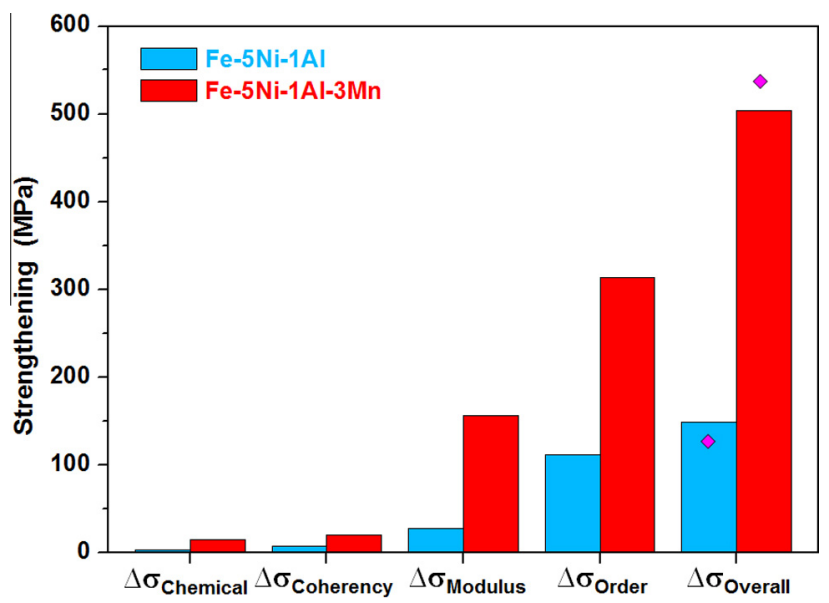

Fig. 9. Strengthening contributions of chemical strengthening, coherency strengthening, modulus strengthening and order strengthening in the $\mathrm{Fe}-5 \mathrm{Ni}-1 \mathrm{Al}$ and $\mathrm{Fe}-5 \mathrm{Ni}-1 \mathrm{Al}-3 \mathrm{Mn}$ alloys. 
the experimental values from the tensile tests, i.e. $\sim 133$ and $540 \mathrm{MPa}$, respectively, as indicated by the two purple spots in Fig. 9.

\section{Summary}

Based on the systematic study of the effects of the Mn partitioning on the nanoscale precipitation mechanisms and hardening of the ferritic steels strengthened by $\mathrm{NiAl}$ nanoparticles, the following conclusions are drawn:

1. APT reveals that $\mathrm{Mn}$ preferentially partitions to the $\mathrm{NiAl}$ nanoparticles and dramatically increases the particle number density (by more than an order of magnitude), leading to a threefold enhancement in strengthening. The mechanism for the Mn partitioning to the $\mathrm{NiAl}$ nanoparticles is due to the high level of chemical interaction and good compatibility of Mn with the NiAl phase.

2. Atomistic structural analyses reveal that $\mathrm{Mn}$ is energetically favored to occupy the Al sublattice, which not only increases the driving force, but also reduces the strain energy for nucleation, thereby significantly decreasing the critical energy for formation of the NiAl nanoparticles in the ferritic alloys. As a result, the Mn partitioning dramatically increases the number density of the NiAl nanoparticles and refines the particle size.

3. The strengthening mechanisms of the NiAl nanoparticles are quantitatively analyzed in terms of chemical strengthening, coherency strengthening, modulus strengthening and order strengthening. The contributions of chemical strengthening and coherency strengthening are relatively small. Modulus strengthening and order strengthening play major roles in strengthening the alloys.

4. With a small amount of Mn additions, new highstrength high-ductility ferritic steels have been developed, which may serve as a prototype for the future development of advanced nanoparticle-strengthened steels.

\section{Acknowledgments}

This research was supported by the internal funding from City University of Hong Kong (account CityU No. 9380060). Atom probe tomography was conducted (by M.K.M.) at the Center for Nanophase Materials Sciences, which is a DOE Office of Science User Facility.

\section{References}

[1] Z.K. Teng, G. Ghosh, M.K. Miller, S. Huang, B. Clausen, D.W. Brown, et al., Acta Mater. 60 (2012) 5362

[2] Z. Sun, C.H. Liebscher, S. Huang, Z. Teng, G. Song, G. Wang, et al., Scr. Mater. 68 (2013) 384.

[3] Y. Liao, F. Meng, I. Baker, Philos. Mag. 91 (2011) 3547.

[4] G. Trotter, G. Rayner, I. Baker, P.R. Munroe, Intermetallics 53 (2014) 120.

[5] Y. Yamamoto, G. Muralidharan, M.P. Brady, Scr. Mater. 69 (2013) 816.
[6] H. Gleiter, Acta Mater. 48 (2000) 29.

[7] T. Hayashi, P.M. Sarosi, J.H. Schneibel, M.J. Mills, Acta Mater. 56 (2008) 1407.

[8] M.J. Alinger, G.R. Odette, D.T. Hoelzer, Acta Mater. 57 (2009) 392.

[9] J.S. Wang, M.D. Mulholland, G.B. Olson, D.N. Seidman, Acta Mater. 61 (2013) 4939.

[10] H.A. Calderon, M.E. Fine, J.R. Weertman, Metall. Trans. A 19 (1988) 1135.

[11] Y. Yamamoto, M.P. Brady, Z.P. Lu, P.J. Maziasz, C.T. Liu, B.A. Pint, et al., Science 316 (2007) 433.

[12] X.Q. Xu, X.F. Zhang, G.L. Chen, Z.P. Lu, Mater. Lett. 65 (2011) 3285.

[13] R.P. Kolli, Z. Mao, D.N. Seidman, D.T. Keane, Appl. Phys. Lett. 91 (2007) 241903.

[14] Z.K. Teng, M.K. Miller, G. Ghosh, C.T. Liu, S. Huang, K.F. Russell, et al., Scr. Mater. 63 (2010) 61.

[15] H. Leitner, M. Schober, R. Schnitzer, Acta Mater. 58 (2010) 1261.

[16] J.M. Yang, S.M. Jeng, K. Bain, R.A. Amato, Acta Mater. 45 (1997) 295.

[17] C.T. Liu, C.L. Fu, M.F. Chisholm, J.R. Thompson, M. Krcmar, X.L. Wang, Prog. Mater. Sci. 52 (2007) 352.

[18] R.J. Thompson, J.C. Zhao, K.J. Hemker, Intermetallics 18 (2010) 796.

[19] R. Taillard, A. Pineau, B.J. Thomas, Mater. Sci. Eng. 54 (1982) 209.

[20] Z.W. Zhang, C.T. Liu, M.K. Miller, X.L. Wang, Y.R. Wen, T. Fujita, et al., Sci. Rep. 3 (2013) 1327.

[21] N.Q. Vo, C.H. Liebscher, M.J. Rawlings, M. Asta, D.C. Dunand, Acta Mater. 71 (2014) 89.

[22] Z.B. Jiao, J.H. Luan, Z.W. Zhang, M.K. Miller, C.T. Liu, Scr. Mater. 87 (2014) 45.

[23] X.Q. Xu, X.F. Zhang, X.Y. Sun, Z.P. Lu, Oxid. Met. 78 (2012) 349.

[24] O. Dmitrieva, D. Ponge, G. Inden, J. Millán, P. Choi, J. Sietsma, et al., Acta Mater. 59 (2011) 364.

[25] F.B. Pickering, Physical Metallurgy and Design of Steels, Applied Science Publisher, London, 1978.

[26] M.K. Miller, Atom Probe Tomography: Analysis at the Atomic Level, Springer, New York, 2000.

[27] G. Kresse, J. Furthmüller, Phys. Rev. B 54 (1996) 11169.

[28] J.P. Perdew, K. Burke, M. Ernzerhof, Phys. Rev. Lett. 77 (1996) 3865.

[29] W. Hume-Rothery, E. Anderson, Philos. Mag. 5 (1960) 383.

[30] A. Takeuchi, A. Inoue, Mater. Trans. JIM 46 (2005) 2817.

[31] C.L. Fu, J. Zou, Acta Mater. 44 (1996) 1471.

[32] Y. Song, Z.X. Guo, R. Yang, D. Li, Acta Mater. 49 (2001) 1647.

[33] A. Hirata, T. Fujita, C.T. Liu, M.W. Chen, Acta Mater. 60 (2012) 5686.

[34] Z.B. Jiao, J.H. Luan, Z.W. Zhang, M.K. Miller, W.B. Ma, C.T. Liu, Acta Mater. 61 (2013) 5996.

[35] M. Kapoor, D. Isheim, G. Ghosh, S. Vaynman, M.E. Fine, Y.W. Chung, Acta Mater. 73 (2014) 56.

[36] J. Millán, S. Sandlöbes, A. Al-Zubi, T. Hickel, P. Choi, J. Neugebauer, et al., Acta Mater. 76 (2014) 94.

[37] H.I. Aaronson, F.K. LeGoues, Metall. Trans. A 23 (1992) 1915.

[38] E. Povoden-Karadeniz, E. Kozeschnik, ISIJ Int. 52 (2012) 60.

[39] A. Kelly, R.B. Nicholson, Strengthening Methods in Crystals, Elsevier, London, 1971.

[40] K.C. Russell, L.M. Brown, Acta Metall. 20 (1972) 969.

[41] W. Lin, J.H. Xu, A.J. Freeman, J. Mater. Res. 7 (1992) 592. 